Supporting Information

\title{
Photopolymerizable, Universal Antimicrobial Coating to Produce High-Performing, Multifunctional Face
}

\section{Masks}

Surjith Kumaran, ${ }^{\dagger}$ Euna Oh, ${ }^{\dagger}$ Sumin Han, and Hyo-Jick Choi ${ }^{\star}$

Department of Chemical and Materials Engineering, University of Alberta, Edmonton, AB T6G 1H9, Canada.

${ }^{\dagger}$ Equal contribution.

*Correspondence to: hyojick@ualberta.ca (H.-J.C) 


\section{Supporting Information}

A
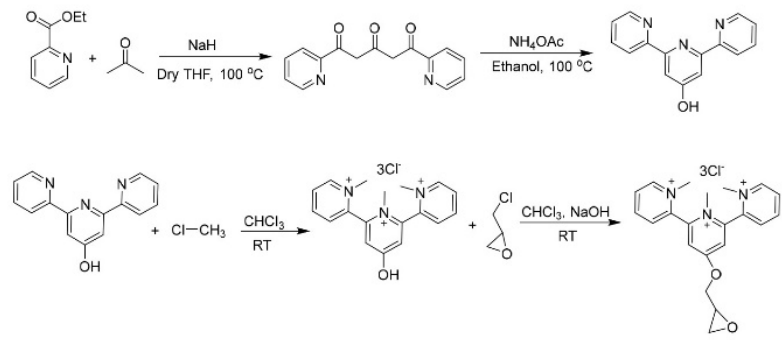

B

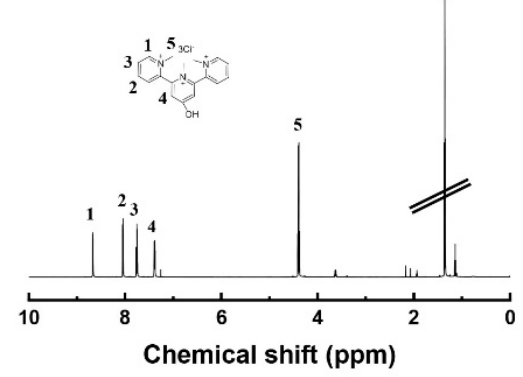

C

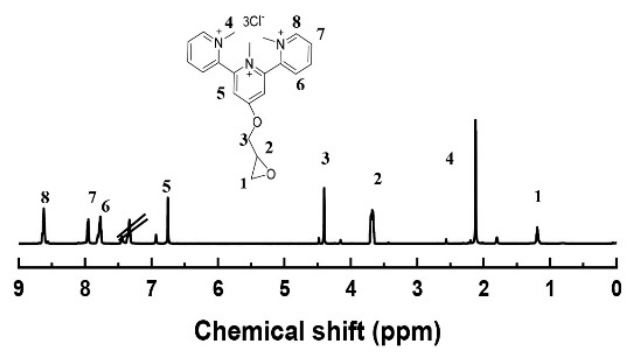

Figure S1. Synthesis of 2,2':6',2"-(terpyridine-1-methylammonium chloride-1-yloxy) methyl epoxide (TMAC). Synthesis scheme of TMAC (A), ${ }^{1} \mathrm{H}$ NMR of 2,2', 6',2"-terpyridine-1methylammonium chloride-1-ol (B), and 2,2':6',2"-(terpyridine-1-methylammonium chloride-1yloxy) methyl epoxide (C). The synthetic pathway for the epoxide functionalizing antimicrobial substance, TMAC, is shown in Figure S1A. First, the terpyridine hydroxide was synthesized according to the previous report ${ }^{1}$. This was obtained through classical Kröhnke and ClaisenSchmidt condensation ${ }^{2,3}$. The synthesis of terpyridine functionalized methylammonium chloride hydroxide was obtained by an $\mathrm{N}$-methyl coupling reaction, where the aromatic tertiary nitrogen atom is quaternized by an aliphatic methyl chloride substituent. The lignin-antimicrobial coupling epoxy group was synthesized by a simple $\mathrm{C}-\mathrm{O}$ - bond formation reaction of a phenol group of terpyridine and epichlorohydrin in the presence of $\mathrm{NaOH}$. The methylation of terpyridine was confirmed by ${ }^{1} \mathrm{H}$ NMR (Figure S1B) analysis as indicated by the chemical shift peaks at $\delta=8.67$ ppm (d, $4 \mathrm{H}$, aromatic), $8.01 \mathrm{ppm}(\mathrm{d}, 4 \mathrm{H}$, aromatic), $7.77 \mathrm{ppm}(\mathrm{s}, 4 \mathrm{H}$, aromatic), $6.7 \mathrm{ppm}(\mathrm{m}, 2$ $\mathrm{H}$, aromatic), and $4.35 \mathrm{ppm}\left(\mathrm{m}, 2 \mathrm{H},-\mathrm{CH}_{2}\right) .{ }^{1} \mathrm{H} \mathrm{NMR}$ in Figure $\mathrm{S} 1 \mathrm{C}$ shows the chemical shift peaks of $\delta=8.7 \mathrm{ppm}(\mathrm{d}, 4 \mathrm{H}$, aromatic), $8.01 \mathrm{ppm}(\mathrm{d}, 4 \mathrm{H}$, aromatic), $7.77 \mathrm{ppm}$ (s, $4 \mathrm{H}$, aromatic), 6.7 ppm (m, $2 \mathrm{H}$, aromatic), $4.35 \mathrm{ppm}\left(\mathrm{m}, 2 \mathrm{H},-\mathrm{CH}_{2}\right), 3.6 \mathrm{ppm}(\mathrm{m}, 2 \mathrm{H},-\mathrm{CH})$, and $2.1 \mathrm{ppm}(\mathrm{m}, 9 \mathrm{H}$, $\mathrm{CH}_{3}$ ), confirming the synthesis of $2,2^{\prime}: 6^{\prime}, 2^{\prime \prime}$-(terpyridine-1-methylammonium chloride-1-yloxy) methyl epoxide (TMAC). 


\section{Supporting Information}
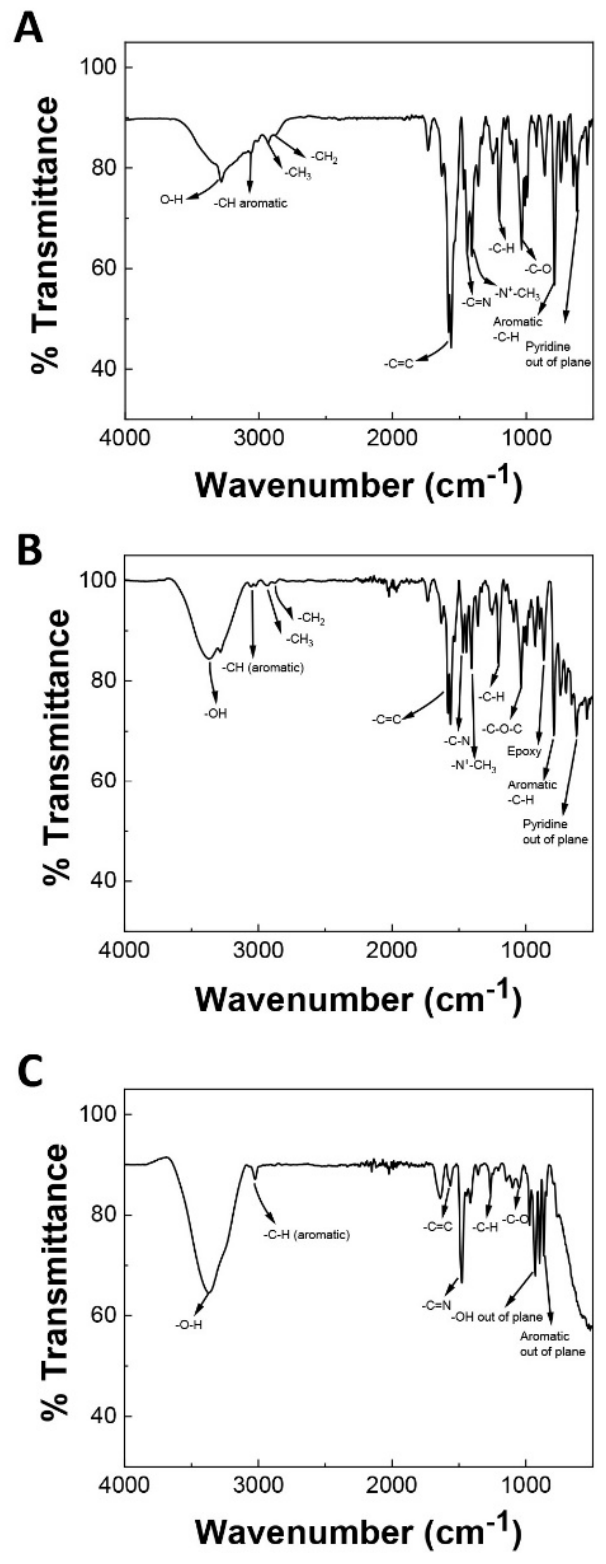

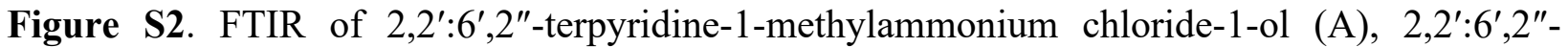
(terpyridine-1-methylammonium chloride-1-yloxy) methyl epoxide (B), 2,2':6',2" -terpyridine hydroxide (C). The FTIR spectrum (Figure S2A) of the 2,2':6',2"-terpyridine-1-methylammonium chloride-1-ol includes the peaks at $3278 \mathrm{~cm}^{-1}$ (-OH asymmetric stretching), $3059 \mathrm{~cm}^{-1}$ (aromatic $-\mathrm{CH}$ asymmetric stretching), $2945 \mathrm{~cm}^{-1}$ (aliphatic $-\mathrm{CH}_{3}$ asymmetric stretching), $2874 \mathrm{~cm}^{-1}$ (aliphatic $-\mathrm{CH}_{2}$ asymmetric stretching), $1574 \mathrm{~cm}^{-1}$ (aromatic $-\mathrm{C}=\mathrm{C}$ symmetric stretching), 1441 $\mathrm{cm}^{-1}$ (-C-N symmetric stretching), $1404 \mathrm{~cm}^{-1}$ (- $\mathrm{N}^{+}-\mathrm{CH}_{3}$ symmetric stretching), $1215 \mathrm{~cm}^{-1}$ (-C-H symmetric stretching), $1037 \mathrm{~cm}^{-1}$ (-C-O symmetric stretching), $799 \mathrm{~cm}^{-1}$ (aromatic $-\mathrm{C}-\mathrm{H}$ out of plane stretching), and $612 \mathrm{~cm}^{-1}$ (pyridine aromatic out of plane deformation vibration). The FTIR spectrum (Figure S2B) of the 2,2':6',2'-(terpyridine-1-methylammonium chloride-1-yloxy) 


\section{Supporting Information}

methyl epoxide shows the corresponding peaks at $3357 \mathrm{~cm}^{-1}$ (-OH asymmetric stretching), 3059$3011 \mathrm{~cm}^{-1}$ (aromatic -CH stretching), $2934 \mathrm{~cm}^{-1}$ (aliphatic $-\mathrm{CH}_{2}$ asymmetric stretching), 2872 $\mathrm{cm}^{-1}$ (aliphatic $-\mathrm{CH}_{3}$ asymmetric stretching), $1572 \mathrm{~cm}^{-1}$ (aromatic $-\mathrm{C}=\mathrm{C}$ symmetric stretching), $1469 \mathrm{~cm}^{-1}$ (-C-N symmetric stretching), $1403 \mathrm{~cm}^{-1}$ (-N $-\mathrm{N}_{3} \mathrm{CH}_{3}$ symmetric stretching), $1203 \mathrm{~cm}^{-1}$ ($\mathrm{C}-\mathrm{H}$ symmetric stretching), $1033 \mathrm{~cm}^{-1}$ (-C-O symmetric stretching), $862 \mathrm{~cm}^{-1}$ (epoxy ring stretching), $791 \mathrm{~cm}^{-1}$ (aromatic -C-H out of plane stretching), and $615 \mathrm{~cm}^{-1}$ (pyridine aromatic out of plane deformation vibration). The FTIR spectrum (Figure S2C) of the starting material, $2,2^{\prime}: 6^{\prime}, 2^{\prime \prime}$-terpyridine hydroxide, shows the corresponding peaks at $3371 \mathrm{~cm}^{-1}$ (-OH asymmetric stretching), $3020 \mathrm{~cm}^{-1}$ (aromatic -CH stretching), $1554 \mathrm{~cm}^{-1}$ (aromatic $-\mathrm{C}=\mathrm{C}$ symmetric stretching), $1469 \mathrm{~cm}^{-1}$ (-C-N symmetric stretching), $1266 \mathrm{~cm}^{-1}$ (-C-H symmetric stretching), 1037 $\mathrm{cm}^{-1}$ (-C-O symmetric stretching), $924 \mathrm{~cm}^{-1}$ (-O-H out of plane stretching), and $853 \mathrm{~cm}^{-1}$ (aromatic out of plane stretching). These results indicate successful synthesis of precursor materials for synthesizing TMAC. 


\section{Supporting Information}

A



Figure S3. Synthesis of N-9(Adenine $N$-hexyl ammonium chloride) $N$-6 methyl epoxide (AHAC). Synthesis scheme (A), ${ }^{1} \mathrm{H}$ NMR (B) and FTIR (C) of AHAC. The antimicrobial AHAC was synthesized by the one-pot coupling of adenine, 1-chloro hexane, and epichlorohydrin. Despite many $\mathrm{C}-\mathrm{N}$ based heterocyclic reactions reported, very few show one-pot synthesis of adenine based $\mathrm{N}$-alkylation reported ${ }^{4}$. The multiple aromatic nitrogen can induce a stable $\mathrm{N}$-alkyl reaction (Figure S3B) as evident by the ${ }^{1} \mathrm{H}$ NMR peaks at 8.53 (s, 1H, Aromatic), $7.6(\mathrm{~s}, 1 \mathrm{H}$, Aromatic), 6.57 (s, $1 \mathrm{H}$, Aromatic), $4.46\left(\mathrm{~s}, 1 \mathrm{H}, \mathrm{NH}-\mathrm{CH}_{2}\right), 3.42\left(-\mathrm{N}^{+}-\mathrm{CH}_{2}-\right), 2.0\left(-\mathrm{CH}_{2}-\right.$, Aliphatic), 1.73 (-O$\left.\mathrm{CH}_{2}\right), 1.03\left(-\mathrm{CH}_{2}-\mathrm{CH}_{2}-\right)$ of AHAC in $d_{6}$ DMSO. Similarly, FTIR spectrum (Figure S3C) of the AHAC indicates the successful synthesis of AHAC as evidenced by the observation of the peaks at $1635 \mathrm{~cm}^{-1}$ (aromatic $-\mathrm{C}=\mathrm{C}$ symmetric stretching), $1592 \mathrm{~cm}^{-1}(-\mathrm{C}=\mathrm{N}$ symmetric stretching), 1418 $\mathrm{cm}^{-1}$ (- $\mathrm{N}^{+}-\mathrm{CH}_{2}$ symmetric stretching), $1254 \mathrm{~cm}^{-1}$ (aromatic -C-N symmetric stretching), and 1210 $\mathrm{cm}^{-1}$ (epoxy bending). 


\section{Supporting Information}

A



B

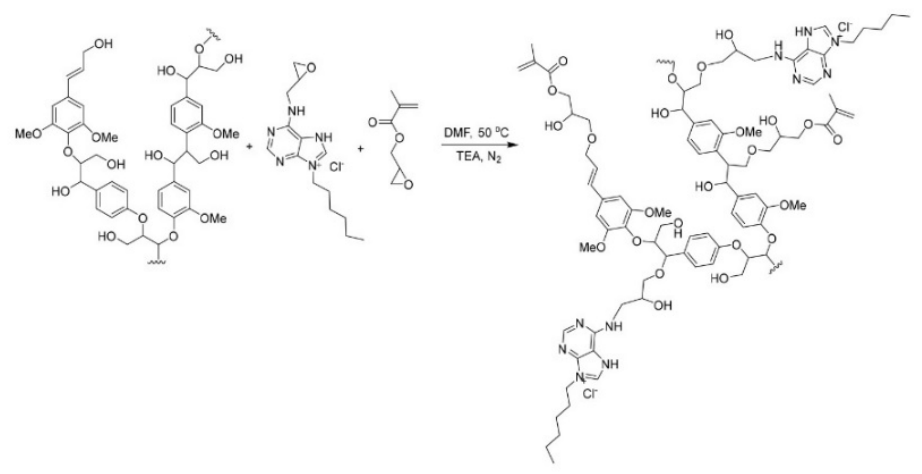

Figure S4. Schematic of LTMAC (A) and LAHAC (B) synthesis. 


\section{Supporting Information}

A

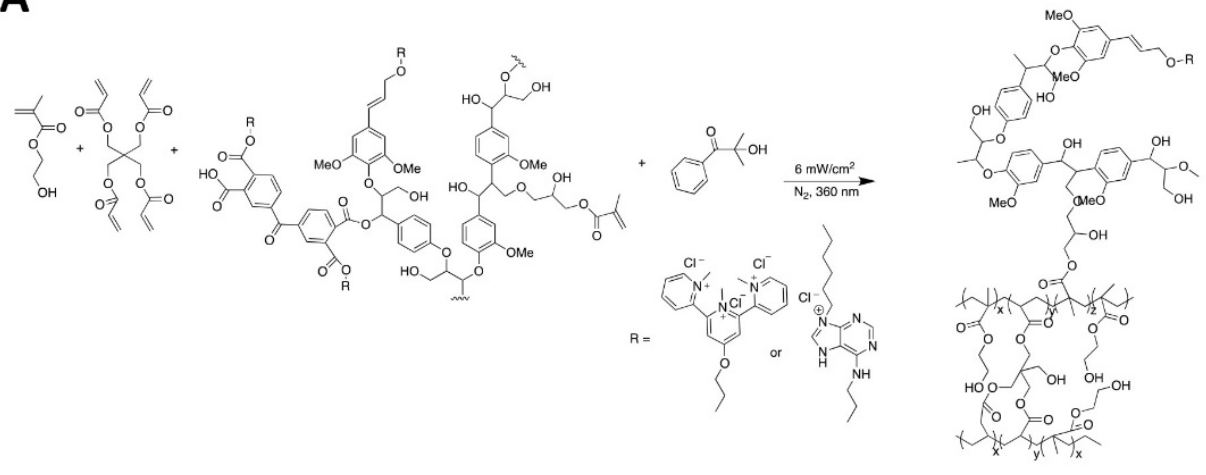

B

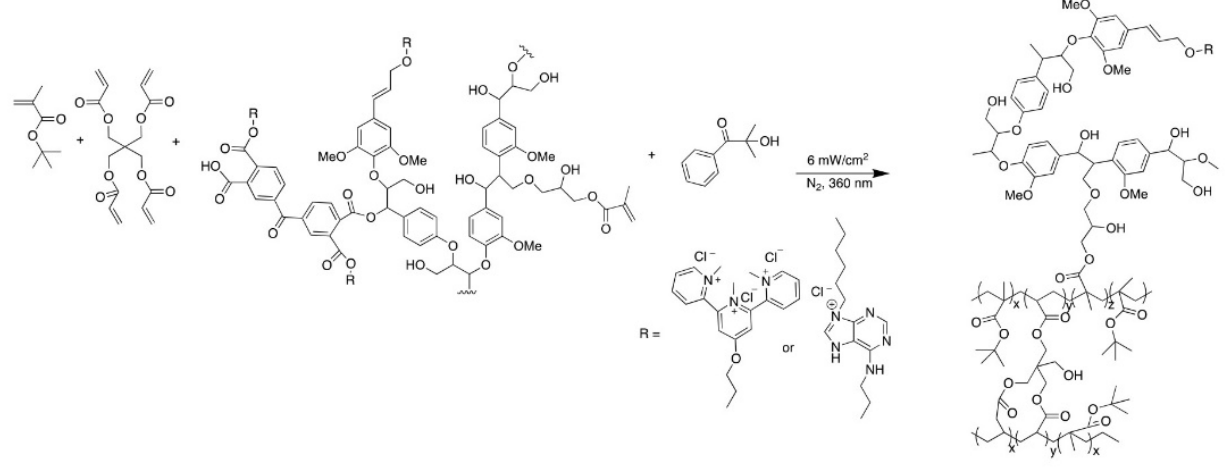

Figure S5. Synthesis scheme of hydrophilic (A) and hydrophobic (B) LTMAC/LAHAC-polymer coating via UV-induced cross-linking polymerization. UV-induced polymer coating is a faster way to fabricate hydrophilic (HYP) or hydrophobic (HYD) antimicrobial polymer coating on PP fabrics. The polymerization solution contains 95\% 2-hydroxyethyl methacrylate (HEMA) (for hydrophilic coating) or tert-butyl methacrylate (for hydrophobic coating), $4.9 \%$ of penaerythritol tatraacrylate (cross-linker), $750 \mathrm{mg}$ of LTMAC or LAHAC, and 0.1\% hydroxy-2-methylpropiophenone (UV initiator) in DMF solvent. 


\section{Supporting Information}

A


Figure S6. Filtration efficiency of spunbond PP fabrics (inner and outer layers of Tian brand surgical mask) with HPL and HYD antimicrobial polymer coatings (A) (one-way ANOVA, $n=7$ 12 , mean $\pm \mathrm{SD}$ ). Filtration efficiency of inner layer of surgical mask (a: Fischer brand), cotton masks (b: DSCover, c: TSI), and spunbond outer layer of N95 respirators (d: Honeywell-Sperian, e: $3 \mathrm{M}-8210$ ) (student's $t$-test, $n=5$, mean $\pm \mathrm{SD}$ ). 


\section{Supporting Information}

\section{A}

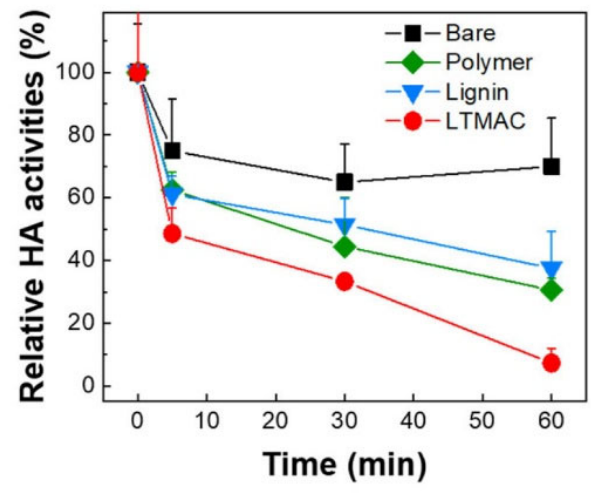

B

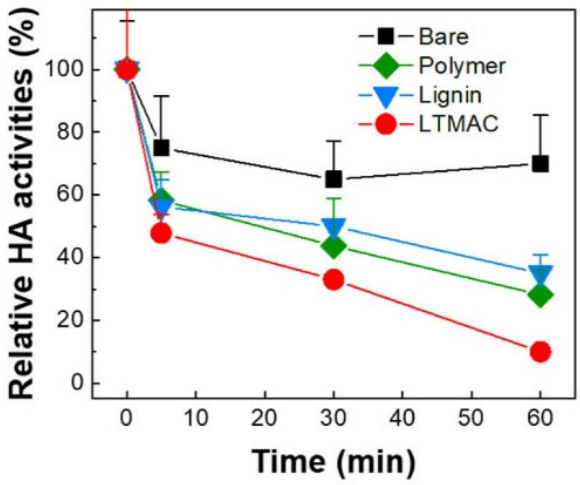

Figure S7. Time-dependent inactivation of influenza virus on antimicrobial spunbond fabrics. Remaining HA activities of PR8 droplets (A: HPL PP fabric, B: HYD PP fabric) ( $n=6-8$, mean $\pm \mathrm{SD})$. HA activity data in (A) and (B) indicates that PR8 virus in droplets showed time-dependent inactivation on the HPL and HYD LTMAC-coated spunbond fabrics (GML, $P<0.0001$ ). The antimicrobial effect is mainly induced by antimicrobial moieties coupled to lignin. Bare, HPL LTMAC, and HYD LTMAC HA activity data shown in Figure 3A are included in the plots for comparison with other materials. (Polymer: cross-linked polymer coating only and lignin: ligninfunctionalized polymer coating without antimicrobial moieties) 


\section{Supporting Information}

\section{A}



B

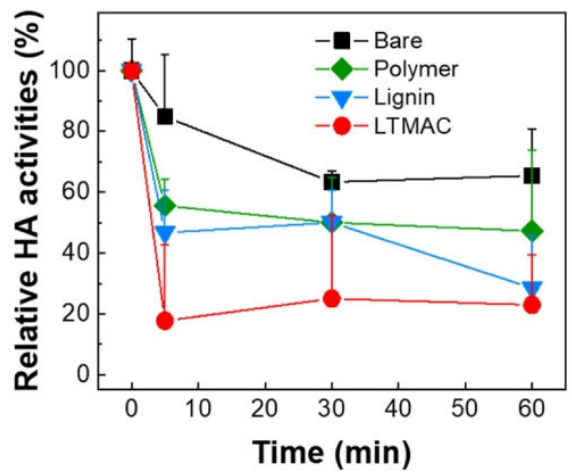

Figure S8. Time-dependent inactivation of influenza virus on antimicrobial meltblown fabrics. Remaining HA activities of virus-carrying aerosols (A) and droplets (B, HYD PP fabric) $(n=5-12$, mean $\pm \mathrm{SD}$ ). 


\section{Supporting Information}



Figure S9. FTIR spectra of spunbond PP coated with a mixture of LTMAC and LAHAC. The spunbond PP with a monomer mixture of LTMAC and LAHAC, and with a 50:50 weight ratio shows peaks at a lower $-\mathrm{C}=\mathrm{O}$ stretching vibration at $1720 \mathrm{~cm}^{-1},-\mathrm{N}^{+}-\mathrm{CH}_{3}$ stretching at $1404 \mathrm{~cm}^{-1}$, and $-\mathrm{N}^{+}-\mathrm{CH}_{2}$ vibration peak at $1375 \mathrm{~cm}^{-1}$, compared to 10:90. With the increase of LAHAC concentration from $50 \%$ to $90 \%$, the $-\mathrm{N}^{+}-\mathrm{CH}_{2}$ stretching shifted from $1365 \mathrm{~cm}^{-1}$ to $1375 \mathrm{~cm}^{-1}$. 


\section{Supporting Information}


Figure S10. Gene expression level change of PR8 influenza virus (A), HCoV-229E (B) and $\mathrm{HCoV}-\mathrm{OC} 43$ (C) on spunbond PP fabrics with cross-linked antimicrobial coatings that have different weight ratios of antimicrobial moieties (LTMAC:LAHAC $=50: 50,10: 90)(n=3$, mean $\pm \mathrm{SD})$. 


\section{Supporting Information}

A



C



E


B
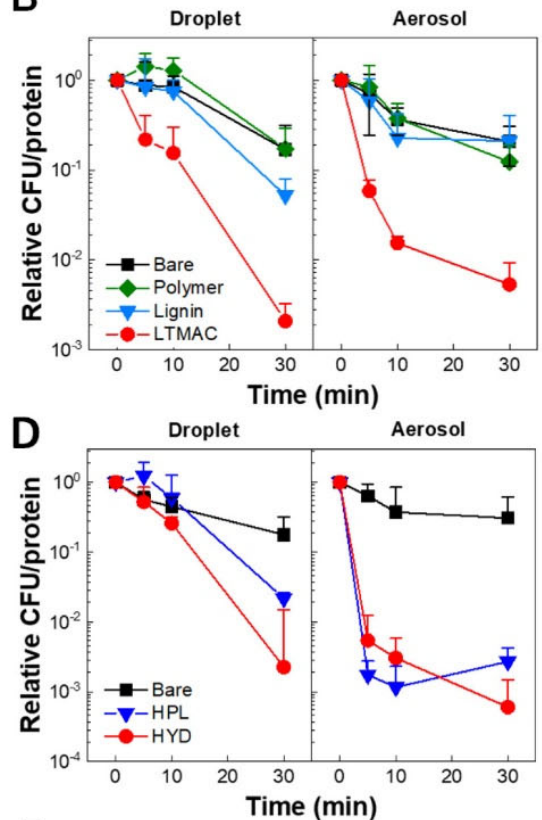

$\mathbf{F}$


Figure S11. Time-dependent inactivation of $K$. pneumoniae upon exposure to the spunbond, meltblown, and spunbond-N95. K. pneumoniae in DI water exposed to HPL LTMAC-coated spunbond fabric ( $n=3-4$, mean \pm SD) (A) and HYD LTMAC-coated spunbond fabric $(n=3-4$, mean \pm SD) (B), K. pneumoniae in artificial saliva exposed to HPL and HYD LTMAC-coated spunbond fabrics ( $n=4-8$, mean $\pm \mathrm{SD})(\mathrm{C})$, $K$. pneumoniae in DI water $(n=3-8$, mean $\pm \mathrm{SD})(\mathrm{D})$ and in artificial saliva $(n=4$, mean $\pm \mathrm{SD})(\mathrm{E})$ exposed to HPL and HYD LTMAC-coated meltblown fabric, K. pneumoniae in DI water droplets exposed to HYD LTMAC-coated spunbond-N95 ( $n=4-8$, mean $\pm \mathrm{SD})(\mathrm{F})$, HYD LAHAC-coated spunbond PP fabric $(\mathrm{G})$, and HYD LAHAC-coated meltblown fabric and spunbond-N95 $(n=4$, mean \pm SD) $(\mathrm{H})$. 


\section{Supporting Information}

\section{Methods}

\section{Materials and coating method}

All reactions were conducted in a nitrogen environment. Reagents, 2-hydroxyethyl methacrylate, inhibitor removal resin, pentaerythritol tetraacrylate, hydroxy-2methylpropiophenone, tert-butyl methacrylate dimethyl formamide, glycidyl methacrylate, inhibitor remover, sodium hydride $(\mathrm{NaH})$, anhydrous tetrahydrofuran (THF), methyl chloride, 1chloro hexane, ammonium acetate, sodium hydroxide $(\mathrm{NaOH})$, adenine, softwood Kraft lignin powder, and ethyl-picolinate, purchased from Sigma Aldrich Canada (Oakville, ON, Canada), were used as received, unless otherwise stated. Surgical masks (Tians-40578-RS5, Fisher scientific-12888001A), N95 respirators (Honeywell-Sperian and 3M-8210), acetone, diethyl ether, ethanol, magnesium sulfate, and Whatman qualitative filter paper (No. 4) were purchased from Fisher Scientific (Pittsburgh, PA, USA). 100\% Cotton masks (DSCover and TSI) were purchased from Amazon Inc (Toronto, ON, Canada). Surgical masks (Tian) and N95 respirators (3M), not otherwise specified, were used for experiments.

Monomers such as 2-hydroxyethyl methacrylate, tert-butyl methacrylate, and cross-linker penaerythritol tatraacrylate were passed through inhibitor removal resin, prior to use. Solvent concentration in vacuo was performed using a rotary evaporator with a water bath at $40{ }^{\circ} \mathrm{C}$, followed by further concentration using a high-vacuum pump. UV cross-linking was performed using RealUV-LED (Waveform Lighting; Vancouver, WA, USA). Spunbond PP fabrics ( 22 $\left.\mathrm{g} / \mathrm{m}^{2}\right)$, meltblown PP filters $\left(\sim 20 \mathrm{~g} / \mathrm{m}^{2}\right)$, and spundbond PP fabrics $\left(\sim 25 \mathrm{~g} / \mathrm{m}^{2}\right)$ were obtained from the outer, middle, and inner layer of the three-ply surgical masks. Unless otherwise specified, spunbond and meltblown fabrics indicate the outer and middle layer of the surgical mask, respectively. Outer layer PP fabrics (spunbond, $\sim 50 \mathrm{~g} / \mathrm{m}^{2}$ ) of N95 (hereafter abbreviated as 


\section{Supporting Information}

spunbond-N95) were also used to evaluate the universal applicability of the antimicrobial coatings. PP fabrics cut into circular pieces $\left(2.4-4 \mathrm{~cm}^{2}\right)$ were lightly soaked in antimicrobial coating formulations, and excess coating solution was removed by applying a vacuum (10 in. $\mathrm{Hg}$ ) for 10 seconds on each side of the mask. Alternatively, samples could also be coated using a spraycoating system, which is a custom-made spray equipped with an atomizing nozzle (Spraying system co.; Wheaton, IL, USA) and operated with compressed nitrogen gas (operation at $40 \mathrm{psi}$ ). Coating formulation was spray-coated onto spunbond or meltblown mask fabrics at a height of 15 $\mathrm{cm}$ for $5 \mathrm{sec}$ (spray solution flow rate: $\sim 15 \mathrm{~mL} / \mathrm{s}$ ). The excessive coating solution was removed by applying a vacuum (10 in. $\mathrm{Hg}$ ) for 10 seconds on each side of the mask. For this work, we mainly prepared samples via the dip-coating method. The spunbound and meltblown fabrics coated with antimicrobial polymers were cured for 1 minute using UV light with a power density of 6 $\mathrm{mW} / \mathrm{cm}^{2}$. The UV cured fabric was washed 3 times with $1 \mathrm{~mL}$ of ethanol, and then 5 times with 1 $\mathrm{mL}$ of water. Then, coated fabrics were dried at $37{ }^{\circ} \mathrm{C}$ for 12 hours to obtain $\mathrm{HYD} / \mathrm{HPL}$ LTMAC/LAHAC.

\section{Synthesis of the antimicrobial substance and fabrication of the face mask fabrics with antimicrobial coatings}

\subsection{2,2':6',2"-terpyridine-1-methylammonium chloride (1)}

$6 \mathrm{~g}(0.120 \mathrm{~mol})$ of chloromethane was added to a RT solution of $2,2^{\prime}: 6^{\prime}, 2^{\prime \prime}$-terpyridine hydroxide ( $5 \mathrm{~g}, 0.02 \mathrm{~mol})$ in $20 \mathrm{~mL}$ chloroform under a $\mathrm{N}_{2}$ atmosphere. This process was followed by stirring for 4 hours. Then the crude mixture was slowly poured into $300 \mathrm{~mL}$ of diethyl ether with continuous stirring to obtain a white precipitate. The precipitated product was filtered by grade 4 Whatman filter paper, then washed with another $200 \mathrm{~mL}$ of diethyl ether. The precipitate 


\section{Supporting Information}

was further purified by a repeated precipitation (i.e., dissolving in chloroform and precipitating in diethyl ether, 3 times). The solvent was removed under high vacuum to obtain $7.5 \mathrm{~g}$ (yield: 95\%) of white powder $\mathbf{1}$.

\subsection{2,2':6',2"-(terpyridine-1-methylammonium chloride-1-yloxy) methyl epoxide (2)}

$2 \mathrm{~g}(0.122 \mathrm{~mol})$ of epichlorohydrin was added to a solution of $5 \mathrm{~g}(0.02 \mathrm{~mol})$ of $2,2^{\prime}: 6^{\prime}, 2^{\prime \prime}-$ terpyridine-1-methylammonium chloride (1) in $20 \mathrm{~mL}$ of anhydrous chloroform. In a separate 25 $\mathrm{mL}$ round bottom flask, $0.01 \mathrm{mmol}$ of sodium hydroxide in $5 \mathrm{~mL}$ of anhydrous ethanol was prepared. Then the solution was added to the first reaction mixture, stirred at $60^{\circ} \mathrm{C}$ for 3 hours, and stirred again at RT for 4 hours. After the reaction, the solvent was removed using a rotary evaporator at $40{ }^{\circ} \mathrm{C}$. The resulting product was dissolved in $30 \mathrm{~mL}$ of chloroform, and extracted with $10 \mathrm{~mL}$ of DI water, 3 times. Anhydrous magnesium sulfate $\left(\mathrm{MgSO}_{4}\right)$ was added into the product dissolved in $\mathrm{CHCl}_{3}$ until the solution became clear. After the solvent was removed using a rotary evaporator, the solid was dissolved in chloroform and slowly poured into $300 \mathrm{~mL}$ of diethyl ether, while stirring continuously to yield a yellowish precipitate. The precipitation product was filtered by Whatman filter paper (grade 4) and washed with another $200 \mathrm{~mL}$ of cold, $4{ }^{\circ} \mathrm{C}$ diethyl ether. The precipitate was filtered and dried under vacuum to obtain $5.28 \mathrm{~g}$ (yield: $92 \%$ ) of product 2.

\subsection{Synthesis of $N-9(N$-hexyl adenine ammonium chloride) $N-6$ methyl epoxide (3)}

Under a nitrogen atmosphere, $5 \mathrm{~g}(0.037 \mathrm{~mol})$ of adenine was dissolved in $25 \mathrm{~mL}$ of dry DMF in a $50 \mathrm{~mL}$ round bottom flask. This was followed by the addition of $2 \mathrm{~g}(0.022 \mathrm{~mol})$ of epichlorohydrin and $2.4 \mathrm{~g}(0.022 \mathrm{~mol})$ of 1-chloro hexane. The reaction flask was then immersed 


\section{Supporting Information}

in a silicon oil bath at $60{ }^{\circ} \mathrm{C}$ and stirred for $14 \mathrm{hrs}$. After the reaction, the crude mixture was continuously stirred while being slowly poured into $400 \mathrm{~mL}$ of diethyl ether to yield a white precipitate. The precipitation product was filtered by Whatman filter paper (grade 4), then washed with $100 \mathrm{~mL}$ of cold diethyl ether. The precipitation procedure was repeated 3 times. The precipitate was further purified by stirring in $25 \mathrm{~mL}$ of diethyl ether for 30 minutes and filtering the mixture 3 times. The white precipitate was filtered and dried under vacuum to obtain $9.97 \mathrm{~g}$ (yield: $86 \%$ ) of product 3 .

\subsection{Fabrication of hydrophobic antimicrobial polymer coatings: HYD LTMAC (4), HYD LAHAC (5), HPL (6), and HPL (7)}

In a $5 \mathrm{~mL}$ Eppendorf tube, $2 \mathrm{~mL}$ of a polymerization solution containing $95 \mathrm{w} / \mathrm{w} \%$ tertbutyl methacrylate (TBMA), $4.9 \mathrm{w} / \mathrm{w} \%$ of penaerythritol tatraacrylate (cross-linker), and 0.1 $\mathrm{w} / \mathrm{w} \%$ hydroxy-2-methylpropiophenone (UV initiator) was mixed all together in $5 \mu \mathrm{L}$ of dimethyl formamide (DMF) with $750 \mathrm{mg}$ of LTMAC or LAHAC in $95 \mu \mathrm{L}$ DMF, by vortexing for $2 \mathrm{~min}$. The mixture of monomer, cross-linker, LTMAC, and photo-initiator was then purged with nitrogen $(10 \mathrm{~mL} / \mathrm{min})$ for 3 minutes to remove any dissolved oxygen. In the case of HPL LTMAC and HPL LAHAC, 95\% 2-hydroxyethyl methacrylate (HEMA) was used instead of TBMA. $20 \mu \mathrm{L}$ of the curing solution composed of the monomer, cross-linker, LTMAC, and photo-initiator was then evenly spread on 2.5 or $4 \mathrm{~cm}^{2}$ circular fabrics (spunbond and meltblown). The excess solution was removed by applying a vacuum (10 in. $\mathrm{Hg})$ to each side of the mask fabric for 10 seconds. The LTMAC and LAHAC infused spunbond and meltblown fabrics were then placed on the irradiation chamber and irradiated with $360 \mathrm{~nm}$ LED UV light (power density $6 \mathrm{~mW} / \mathrm{cm}^{2}$ ) for $30 \mathrm{sec}$ on each 


\section{Supporting Information}

side. The UV cured fabric was washed 3 times with $1 \mathrm{~mL}$ of ethanol, followed by 5 times with 1 $\mathrm{mL}$ of water. The coated fabric was dried at $37^{\circ} \mathrm{C}$ for 12 hours to obtain 4-7.

\subsection{Fabrication of HYD LTMAC/LAHAC (50:50) (8) and (10:90) (9)-coated PP fabrics}

In a $5 \mathrm{~mL}$ Eppendorf tube, $2 \mathrm{~mL}$ of polymerization solution containing $95 \%$ tert-butyl methacrylate (TBMA), $4.9 \%$ of penaerythritol tatraacrylate (cross-linker), and $0.1 \%$ Hydroxy-2methylpropiophenone (UV initiator) in $5 \mu \mathrm{L}$ of dimethyl formamide (DMF) was mixed with LTMAC and LAHAC (375 mg of LTMAC and LAHAC each for 50:50, and $75 \mathrm{mg}$ of LTMAC and $675 \mathrm{mg}$ of LAHAC for 10:90) in $95 \mu \mathrm{L}$ DMF by vortex for 2 minutes. The monomer/antimicrobial coating solution was purged with nitrogen $(10 \mathrm{~mL} / \mathrm{min})$ for 3 minutes to remove any dissolved oxygen. The UV cross-linked fabrics ( 8 and $\mathbf{9}$ ) were fabricated following the same procedure as described in $\mathbf{2 . 4}$.

\section{Face mask fabric/filter characterization}

FTIR analysis Attenuated total reflection Fourier transform infrared (ATR-FTIR) analysis was performed using a Bio-Rad FTS Varian 7000 spectrometer equipped with a ZnSe IRE detector. The mask samples (before and after antimicrobial coating on the surgical mask/N95 respirator) were cut into $1 \times 1 \mathrm{~cm}^{2}$ and placed on FTIR-ATR diamond crystal for analysis. The measurements were performed using p-polarized radiation, ( $\mathrm{ZnSe}$ wire grid polarizers) incident at $75^{\circ}$. The spectra were obtained in the region of 4000-500 $\mathrm{cm}^{-1}$ (resolution: $16 \mathrm{~cm}^{-1}$ and scanning number: 100-200 to increase the signal to noise ratio). The background spectra were recorded, prior to analysis.

NMR analysis ${ }^{1} \mathrm{H}$ NMR spectra were recorded using an Agilent Varian VNMRS $600 \mathrm{MHz}$ spectrometer equipped with a Z-axis pulsed-field gradient triple resonance probe. Chemical shifts 


\section{Supporting Information}

$(\delta)$ are reported in ppm, relative to the residual solvent signals $\left(\mathrm{CDCl}_{3}: 7.26 \mathrm{ppm}\right.$ and $d_{6}$-DMSO:

$2.50 \mathrm{ppm}$ ). The NMR peaks were acquired for 32 scans with a relaxation delay of $5 \mathrm{sec}$.

SEM analysis The surface morphology of the face mask fabrics was analyzed in secondary electron mode using scanning electron microscopy (Hitachi S-3000N and Hitachi S4800; Hitachi, Toronto, Canada) at an acceleration voltage of $20 \mathrm{kV}$. The samples were cut into $1 \times 1 \mathrm{~cm}^{2}$ pieces and coated with an $8 \mathrm{~nm}$ thick gold layer using the Denton Desk II sputter coating system.

Contact angle measurement The mask fabrics' wetting properties were characterized by a contact angle measurement using the sessile drop technique ${ }^{5}$. The bare and antimicrobial filters were fixed onto a microscope glass slide $\left(3^{\prime \prime} \times 1^{\prime \prime} \times 0.04^{\prime \prime}\right)$ with tape, and a DI water droplet $(5 \mu \mathrm{L})$ was applied to the surface of the filters using a syringe needle. The contact angles were measured by analyzing images collected with FTA-200 (First Ten Angstroms; Newark, CA, USA). At least 5 sample replicates were used for measurements.

High-performance liquid chromatography (HPLC) analysis The release of chemicals from HPL LTMAC-coated spunbond PP fabrics was characterized using the water extraction technique. Dimethylformamide (DMF; solvent), 2-hydroxyethyl methacrylate (monomer), and hydroxy-2methylpropiophenone (photoinitiator) were tested for releasing from the antimicrobial coated mask. The fabric piece $\left(2.4 \mathrm{~cm}^{2}\right)$ was soaked into $1 \mathrm{~mL}$ of DI water for 10 and $30 \mathrm{~min}$. Then, the chemicals released into water were analyzed using Agilent 1100 infinity HPLC (Santa Clara, CA, USA), coupled with a UV-detector, and the UV-absorption was measured between 200 - $350 \mathrm{~nm}$. A Zorbax SB-C $18(4.6 \times 15 \mathrm{~cm})$ column was used for analysis at $22{ }^{\circ} \mathrm{C}$ and the eluent consisted of acetonitrile $(\mathrm{ACN})$ and methanol at a flow rate of $1 \mathrm{~mL} \cdot \mathrm{min}^{-1}$. Each analysis was carried out three times in order to check repeatability, and three samples were taken for every equilibrated mixture at the given temperature. The average value was used in calculating the final data. 


\section{Supporting Information}

Filtration efficiency and pressure drop tests Filtration efficiency and pressure drop tests were conducted using the procedure reported in the previous study ${ }^{6}$.

TEM analysis The structural stability of the viruses and bacteria was investigated using TEM (JEOL JEM-2100; Peabody, MA, USA). The samples were prepared following the procedure described in ref 6.

\section{Bacteria/virus preparation and antimicrobial performance analysis}

\subsection{Pathogen strains and culture conditions}

K. pneumoniae (ATCC BAA-1705; ATCC, Manassas, VA, USA) was grown overnight at $37{ }^{\circ} \mathrm{C}$ on Mueller Hinton Agar (MH agar; BD, Franklin Lakes, NJ, USA) from a single frozen stock. For the liquid culture of $K$. pneumoniae, a single colony of overnight culture on Mueller Hinton (MH) agar was inoculated into $3 \mathrm{~mL}$ of $\mathrm{MH}$ broth, incubated at $37{ }^{\circ} \mathrm{C}$, and shaken at 200 rpm overnight. The overnight culture broth was diluted 100 times in fresh MH broth and incubated until the early exponential phase.

Influenza virus, $\mathrm{A} /$ Puerto Rico/8/34 (PR8), was inoculated and grown in 10-day old embryonated hen eggs, and the virus was purified from the allantoic fluid, following the previous report ${ }^{5}$. Human coronavirus propagation was conducted following the previous report, with slight modifications ${ }^{7}$. Briefly, HCoV strains, 229E (ATCC ${ }^{\circledR}$ VR-740 ${ }^{\mathrm{TM}}$ ), and OC43 (ATCC® VR$1558^{\mathrm{TM}}$ ) were purchased from ATCC and inoculated/cultured in MRC-5 human fetal lung fibroblast cells (ATCC ${ }^{\circ}$ CCL-171 ${ }^{\mathrm{TM}}$ ). The MRC-5 cell was maintained in DMEM (Corning, NY, USA) that was supplemented with 10\% FBS (Thermo Fisher Scientific; Waltham, MA, USA), 100 $\mathrm{U} / \mathrm{mL}$ penicillin, and $100 \mu \mathrm{g} / \mathrm{mL}$ streptomycin of antibiotics (Thermo Fisher Scientific) at $33^{\circ} \mathrm{C}$ with $5 \% \mathrm{CO}_{2}$ before infection. $\mathrm{HCoV}$ strains, $\mathrm{HCoV}-229 \mathrm{E}$ or $\mathrm{HCoV}-\mathrm{OC} 43$, were infected (MOI 


\section{Supporting Information}

$0.01)$ and propagated in passage $6-7$ of MRC- 5 cells $\left(1.5 \times 10^{7}\right)$ in MEM medium (Thermo Fisher Scientific) supplemented with $2 \%$ FBS, $100 \mathrm{U} / \mathrm{mL}$ penicillin, $100 \mu \mathrm{g} / \mathrm{mL}$ streptomycin, and 1 $\mu \mathrm{g} / \mathrm{mL}$ TPCK treated trypsin (Sigma-Aldrich) with $5 \% \mathrm{CO}_{2}$ for 5 days at $33{ }^{\circ} \mathrm{C}$. Then, the culture medium was centrifuged at $2,800 \times \mathrm{g}$ for $10 \mathrm{~min}$ at $4{ }^{\circ} \mathrm{C}$. The supernatant was filtered through 0.22 $\mu \mathrm{m}$ and centrifuged using ultracentrifuge at 30,000 rpm, for 1 hour. The $\mathrm{HCoV}$ pellet was resuspended in DI water and stored at $4{ }^{\circ} \mathrm{C}$ for further experiments.

\subsection{Bacterial/viral inactivation test}

Antibacterial tests were performed, following the previous study ${ }^{6}$. Briefly, the PP fabric (sample size: $4 \mathrm{~cm}^{2}$ ) was located on the aerosol chamber, and the nebulizer unit was placed on top of the fabric piece. $20 \mu \mathrm{L}$ of a highly concentrated pathogenic strain in DI water or artificial saliva $\left(0.6 \mathrm{~g} / \mathrm{L} \mathrm{Na}_{2} \mathrm{HPO}_{4}, 0.6 \mathrm{~g} / \mathrm{L} \mathrm{CaCl}, 0.4 \mathrm{~g} / \mathrm{L} \mathrm{KCl}, 0.4 \mathrm{~g} / \mathrm{L} \mathrm{NaCl}, 4 \mathrm{~g} / \mathrm{L}\right.$ mucin, $4 \mathrm{~g} / \mathrm{L}$ Urea, and adjust

$\mathrm{pH} 7.2$ with $\mathrm{NaOH})^{8}$ was applied for aerosolization. The fabrics exposed to aerosols were incubated for each time point. After incubation, the bacteria on the face mask fabric was resuspended in $2 \mathrm{~mL}$ of $1 \times \mathrm{PBS}(\mathrm{pH} 7.4)$ and concentrated with centrifugation at 14,000 rpm for $15 \min \left(4^{\circ} \mathrm{C}\right)$. The resuspended K. pneumoniae strain was serially diluted and spread onto an $\mathrm{MH}$ agar plate for colony-forming unit (CFU) counting. The $\mathrm{CFU}$ results were normalized to the total protein amounts of each sample, which were determined by the micro BCA assay (Thermo Fischer Scientific). For the droplet tests, the bacteria stock was prepared in water or artificial saliva solution to an optical density of 0.01 at $600 \mathrm{~nm}$. Then, $20 \mu \mathrm{L}$ ( 4 droplets, $5 \mu \mathrm{L}$ each) of the droplet was placed by using a pipette on top of the fabrics, followed by incubation for 5, 30, and $60 \mathrm{~min}$. After incubation, the bacteria were resuspended in $1 \times \mathrm{PBS}(\mathrm{pH} 7.4)$ and centrifuged for $15 \mathrm{~min}$ at 


\section{Supporting Information}

$14,000 \mathrm{rpm}\left(4^{\circ} \mathrm{C}\right)$. The pellet was resuspended in $1 \times \mathrm{PBS}(\mathrm{pH} 7.4)$, prior to the micro $\mathrm{BCA}$ assay and CFU counting.

Similarly, $7 \mathrm{mg} / \mathrm{mL}$ of PR8 stock was applied for aerosolization on the bare and functionalized filter samples in the inactivation test. After exposure to the aerosolized PR8, the bare and functionalized filters were incubated for 5 and $30 \mathrm{~min}$ at room temperature. The PR8 on filters was collected in $2 \mathrm{~mL}$ of PBS (pH 7.4) and centrifuged at $14,000 \mathrm{rpm}$ and $4{ }^{\circ} \mathrm{C}$, for $15 \mathrm{~min}$. The PR8 pellet was resuspended in PBS. For the droplet test, $20 \mu \mathrm{L}$ (4 droplets, $5 \mu \mathrm{L}$ each) of 1 $\mathrm{mg} / \mathrm{mL} \mathrm{PR} 8, \mathrm{HCoV}-229 \mathrm{E}$, and $\mathrm{HCoV}-\mathrm{OC} 43$ viruses was applied on the bare and functionalized filter. After incubation for 5, 30, and/or 60 minutes, the viruses on filters were collected and resuspended in PBS. The resuspended virus strains were used for quantification of protein concentration using the micro BCA assay, hemagglutination assay, and total RNA isolation.

\subsection{Hemagglutination assay}

After protein quantification, the PR8 was diluted to $0.8 \mu \mathrm{g} / \mathrm{mL}$ with PBS (pH 7.4) and placed into 96-well plate (Corning, NY, USA) with two-fold dilution. An equal volume of $0.7 \%$ Chicken Red Blood Cells (Innovate Research; Novi, MI, USA) in PBS was mixed with the diluted virus. The plates were incubated at room temperature for $30 \mathrm{~min}$ to obtain a titer readout.

\subsection{Long-term environmental stability test}

Antimicrobial activity tests at harsh environmental conditions were conducted following the previous study. ${ }^{5}$ Briefly, the bare and spunbond PP fabrics with HYD LTMAC or LAHAC coatings were incubated in a climate chamber (Memmert HPP260; Memmert, Buchenbach, Germany) at $37{ }^{\circ} \mathrm{C}(50$ and $97 \% \mathrm{RH})$ for 7 days. After incubation, the fabrics were dried under 


\section{Supporting Information}

ambient conditions $\left(21^{\circ} \mathrm{C}, 32 \% \mathrm{RH}\right)$ for 1 hour. This was followed by antiviral performance tests against PR8 influenza virus in droplets $(5 \mu \mathrm{L})$ by measuring expression levels of HA and NP genes.

\subsection{Quantitative RT-PCR analysis}

From the PR8, HCoV-229E and $\mathrm{HCoV}-\mathrm{OC} 43$ exposed to face mask fabrics, viral RNA (Invitrogen; Carlsbad, CA, USA) was isolated following the manufacturers' instructions. The concentration of the isolated viral RNA samples was measured using nanodrop (Nanodrop One; Thermo Fisher Scientific), and each sample was controlled to have the same RNA concentration with RNase free water. The viral RNA samples were synthesized to cDNA with a Reverse Transcription kit (Applied Biosystems; Foster City, CA, USA), following the manufacturers' instructions. Quantification of cDNA was carried out using the SYBR Green PCR Master Mix (Applied Biosystem), and the real-time amplification of PCR products were analyzed using the ABI 7500 Fast Real-Time PCR System (Applied Biosystem). The amplification cycle consisted of one cycle at $95{ }^{\circ} \mathrm{C}$ for $3 \mathrm{~min}$, followed by 40 cycles at $95{ }^{\circ} \mathrm{C}$ for $15 \mathrm{sec}$, and 40 cycles at $60{ }^{\circ} \mathrm{C}$ for $1 \mathrm{~min}$. After the final cycle of PCR, reactions went through melt curve analysis for non-specific binding detection. All RT-qPCR analyses included standard samples for the quantifications. The sequences of primers are presented in Table S2.

\section{Statistical analysis}

Statistical analysis for pressure drop, filtration efficiency, contact angle, and HPLC testes was performed using one-way analysis of variance (ANOVA) and student's $t$-test. We performed statistical analysis for inactivation tests with aerosols and droplets by using general linear model 


\section{Supporting Information}

(GLM) analysis. Statistical analysis was conducted using SPSS version 24 (IBM; Armonk, NY, USA).

Table S1. List of antimicrobial substances and their pathogen inactivation performances.

\begin{tabular}{|c|c|c|c|c|}
\hline Materials & $\begin{array}{l}\text { Pathogen used } \\
\text { in the study }\end{array}$ & $\begin{array}{l}\text { Incubation } \\
\text { time }\end{array}$ & Inactivation efficiency & Ref. \\
\hline $\mathrm{Ag} / \mathrm{CNT}$ & E. coli & $30 \min$ & $91 \%$ inactivation & 9 \\
\hline $\begin{array}{l}\text { Gold nanoparticles with undecanesulfonic } \\
\text { acid-containing ligand }\end{array}$ & Adenovirus-5 & $30 \min$ & no inhibition & 10 \\
\hline $\begin{array}{l}\text { Ag Nanoparticle in poly } \\
\text { (3-hydroxybutyrate-co-3-hydroxyvalerate) } \\
\text { (PHBV) film }\end{array}$ & Murine norovirus & $30 \mathrm{~min}$ & $0.14-0.86 \log$ reduction & 11 \\
\hline Benzalkonium chloride & $\begin{array}{l}\text { Human Adenovirus } \\
\text { Type } 8 \\
\end{array}$ & $1 \mathrm{hr}$ & $1.01 \mathrm{log}$ reduction & 12 \\
\hline $\begin{array}{l}\text { Chloroxylenol/ Benzalkonium chloride } \\
\text { on glass slide }\end{array}$ & $\begin{array}{l}\text { Human Coronavirus } \\
\text { (Strain OC43) }\end{array}$ & $10 \min$ & no inhibition & 13 \\
\hline $\mathrm{ZnO}, \mathrm{Ag}, \mathrm{Zn}$ zeolite powder & $\begin{array}{l}\text { Human Coronavirus } \\
\text { (strains 229E) }\end{array}$ & $1 \mathrm{hr}$ & $0.50 \log$ reduction & 14 \\
\hline $\begin{array}{l}\text { Hyperbranched quaternized polymers } \\
\text { immobilized on glass }\end{array}$ & Polio virus & $1 \mathrm{hrs}$ & No significant reduction & 15 \\
\hline Quaternary ammonium chloride & Polio virus & $10 \mathrm{~min}$ & $0.04-0.15$ log reduction & 16 \\
\hline $\begin{array}{l}\text { Hexadecylated polyethylene imine grafted } \\
\text { glass slide }\end{array}$ & Bacteriophage & $1 \mathrm{hr}$ & $\begin{array}{l}50 \% \text { reduction less than } \\
1 \log \text { reduction }\end{array}$ & 17 \\
\hline $\begin{array}{l}\mathrm{N}-[(11 \text {-benzyloxycarbonyl)undecanoyl]- } \\
\text { functionalized polyethylene imine } \\
\text { on glass slide }\end{array}$ & H1N1 & $30 \mathrm{~min}$ & $\sim 60 \%$ virucidal activity & 18 \\
\hline $\begin{array}{l}\text { immobilized N-alkyl-polyethylene imine } \\
\text { on a glass substrate }\end{array}$ & E. coli & $30 \min$ & $\sim 75 \%$ inactivation & 19 \\
\hline $\begin{array}{l}\text { Copolymer of quaternary ammonium } \\
\text { chloride methacrylate and fluorine-methyl } \\
\text { methacrylate spray coated on cotton fabrics }\end{array}$ & $\begin{array}{l}\text { E. coli and } \\
\text { S. aureus }\end{array}$ & $2 \mathrm{hrs}$ & $82-99 \%$ & 20 \\
\hline $\begin{array}{l}\text { Quaternary ammonium iodide functioned } \\
\text { on stainless steel and filter paper }\end{array}$ & K. pneumoniae & $24 \mathrm{hrs}$ & $87-98 \%$ & 21 \\
\hline
\end{tabular}




\section{Supporting Information}

Table S2. List of primers used in this study.

\begin{tabular}{|c|c|c|c|c|c|}
\hline $\begin{array}{c}\text { Pathogen } \\
\text { strain }\end{array}$ & Target gene & $\begin{array}{c}\text { Primer } \\
\text { name }\end{array}$ & Primer sequence (5' - 3') & $\begin{array}{l}\text { Product size } \\
\text { (bp) }\end{array}$ & Ref. \\
\hline \multirow{4}{*}{$\mathrm{A} / \mathrm{PR} 8 / 34$} & \multirow{2}{*}{$\begin{array}{l}\text { Hemagglutinin } \\
\text { (HA) }\end{array}$} & PR8/HA-F & GGAAAGAAGTCCTCGTGCTATG & \multirow{2}{*}{316} & \multirow{2}{*}{ This study } \\
\hline & & PR8/HA-R & CAATCGTGGACTGGTGTATCTG & & \\
\hline & \multirow{2}{*}{$\begin{array}{l}\text { Nucleoprotein } \\
\text { (NP) }\end{array}$} & PR8/NP-F & GCACGGTCTGCACTCATATT & \multirow{2}{*}{405} & \multirow{2}{*}{ This study } \\
\hline & & PR8/NP-R & TCCTCCACTTCTGGTCCTTAT & & \\
\hline \multirow{4}{*}{$\begin{array}{l}\mathrm{HCoV}- \\
229 \mathrm{E}\end{array}$} & \multirow[b]{2}{*}{ Membrane (M) } & $229 \mathrm{E} / \mathrm{M}-\mathrm{F}$ & TGGCCCCATTAAAAATGTGT & \multirow{2}{*}{574} & \multirow{2}{*}{22} \\
\hline & & 229E/M-R & CCTGAACACCTGAAGCCAAT & & \\
\hline & \multirow{2}{*}{ Envelope (E) } & $229 \mathrm{E} / \mathrm{E}-\mathrm{F}$ & CTCTGGTGTGTGGTGCTTATAG & \multirow{2}{*}{172} & \multirow{2}{*}{ This study } \\
\hline & & $229 \mathrm{E} / \mathrm{E}-\mathrm{R}$ & CTCGTTTAGGGAAAGGGTCTATG & & \\
\hline \multirow{4}{*}{$\begin{array}{l}\mathrm{HCoV}- \\
\mathrm{OC} 43\end{array}$} & \multirow{2}{*}{ Membrane (M) } & OC43/M-F & GGCTTATGTGGCCCCTTACT & \multirow{2}{*}{344} & \multirow{2}{*}{22} \\
\hline & & OC43/M-R & GGCAAATCTGCCCAAGAATA & & \\
\hline & \multirow{2}{*}{ Envelope (E) } & OC43/E-F & TGATGCTTATCTTGCAGACACT & \multirow{2}{*}{240} & \multirow{2}{*}{ This study } \\
\hline & & OC43/E-R & ACGTCATCCACATCAAGGAC & & \\
\hline
\end{tabular}




\section{Supporting Information}

\section{References (Supporting Information)}

1. Zalas, M.; Gierczyk, B.; Cegłowski, M.; Schroeder, G., Synthesis of new dendritic antennalike polypyridine ligands. Chem. Pap. 2012, 66, 733-740.

2. Kroehnke, F., The specific synthesis of pyridines and oligopyridines. Synthesis 1976, 01, $1-24$.

3. Wang, H., Comprehensive organic name reactions. Wiley: 2010.

4. Pineda de las Infantas y Villatoro, M. J.; Unciti-Broceta, J. D.; Contreras-Montoya, R.; Garcia-Salcedo, J. A.; Gallo Mezo, M. A.; Unciti-Broceta, A.; Diaz-Mochon, J. J., Amidecontrolled, one-pot synthesis of tri-substituted purines generates structural diversity and analogues with trypanocidal activity. Sci. Rep. 2015, 5, 9139.

5. Quan, F. S.; Rubino, I.; Lee, S. H.; Koch, B.; Choi, H. J., Universal and reusable virus deactivation system for respiratory protection. Sci. Rep. 2017, 7, 39956.

6. Rubino, I.; Oh, E.; Han, S.; Kaleem, S.; Hornig, A.; Lee, S. H.; Kang, H. J.; Lee, D. H.; Chu, K. B.; Kumaran, S.; Armstrong, S.; Lalani, R.; Choudhry, S.; Kim, C. I.; Quan, F. S.; Jeon, B.; Choi, H. J., Salt coatings functionalize inert membranes into high-performing filters against infectious respiratory diseases. Sci. Rep. 2020, 10, 13875.

7. Lundin, A.; Dijkman, R.; Bergstrom, T.; Kann, N.; Adamiak, B.; Hannoun, C.; Kindler, E.; Jonsdottir, H. R.; Muth, D.; Kint, J.; Forlenza, M.; Muller, M. A.; Drosten, C.; Thiel, V.; Trybala, E., Targeting membrane-bound viral RNA synthesis reveals potent inhibition of diverse coronaviruses including the middle East respiratory syndrome virus. PLoS Pathog. 2014, 10, e1004166. 


\section{Supporting Information}

8. Tlili, C.; Cella, L. N.; Myung, N. V.; Shetty, V.; Mulchandani, A., Single-walled carbon nanotube chemoresistive label-free immunosensor for salivary stress biomarkers. Analyst 2010, $135,2637-2642$.

9. Jung, J. H.; Hwang, G. B.; Lee, J. E.; Bae, G., Preparation of airborne Ag/CNT hybrid nanoparticles using an aerosol process and their application to antimicrobial air filtration.

Langmuir 2011, 27, 10256-10264.

10. Cagno, V.; Andreozzi, P.; D’Alicarnasso, M.; Jacob Silva, P.; Mueller, M.; Galloux, M.; Le Goffic, R. Jones, S. T.; Vallino, M.; Hodek, J.; Weber, J.; Sen, S.; Janecek, E. R.; Bekdemir, A.; Sanavio, B. Martinelli, C.; Donalisio, M.; Rameix Welti, M. A.; Eleouet, J. F.; Han, Y., Broadspectrum non-toxic antiviral nanoparticles with a virucidal inhibition mechanism. Nat. Mater. 2018, 17, 195-203.

11. Castro-Mayorga, J. L.; Randazzo, W.; Fabra, M. J.; Lagaron, J. M.; Aznar, R.; Sánchez, G., Antiviral properties of silver nanoparticles against norovirus surrogates and their efficacy in coated polyhydroxyalkanoates systems. LWT - Food Sci. Technol. 2017, 79, 503-510.

12. Romanowski, E. G.; Yates, K. A.; Shanks, R. M.; Kowalski, R. P., Benzalkonium chloride demonstrates concentration-dependent antiviral activity against adenovirus in vitro. J. Ocul. Pharmacol. Ther. 2019, 35, 311-314.

13. Wood, A.; Payne, D., The action of three antiseptics/disinfectants against enveloped and non-enveloped viruses. J. Hosp. Infect. 1998, 38, 283-295.

14. Bright, K. R.; Sicairos-Ruelas, E. E.; Gundy, P. M.; Gerba, C. P., Assessment of the antiviral properties of zeolites containing metal ions. Food. Environ.Virol. 2009, 1, 37-41. 


\section{Supporting Information}

15. Tuladhar, E.; de Koning, M.C.; Fundeanu, I. R.; Beumer, Duizer, E., Different virucidal activities of hyperbranched quaternary ammonium coatings on poliovirus and influenza virus. Appl. Environ. Microbiol. 2012, 78, 2456-2458.

16. Weber, D. J.; Barbee, S. L; Sobsey, M. D.; Rutala, W. A., The effect of blood on the antiviral activity of sodium hypochlorite, a phenolic, and a quaternary ammonium compound Infect. Control Hosp. Epidemiol. 1999, 20, 821-827.

17. Gelman, F.; Lewis, K.; Klibanov, A. M., Drastically lowering the titer of waterborne bacteriophage PRD1 by exposure to immobilized hydrophobic polycations. Biotechnol. Lett. 2004, 26, 1695-1700.

18. Haldar, J.; An, D. Q.; de Cienfuegos, L. A.; Chen, J. Z.; Klibanov, A. M., Polymeric coatings that inactivate both influenza virus and pathogenic bacteria. Proc. Natl. Acad. Sci. USA 2006, 103, 17667-17671.

19. Milovic, N. M.; Wang, J.; Lewis, K.; Klibanov, A. M., Immobilized N-alkylated polyethylenimine avidly kills bacteria by rupturing cell membranes with no resistance developed. Biotechnol. Bioeng. 2005, 90, 715-722.

20. Lin, J.; Chen, X.; Chen, C.; Hu, J.; Zhou, C.; Cai, X.; Wang, W.; Zheng, C.; Zhang, P.; Cheng, J.; Guo, Z.; Liu, H., Durably antibacterial and bacterially antiadhesive cotton fabrics Coated by cationic fluorinated polymers. ACS Appl. Mater. Interfaces 2018, 10, 6124-6136.

21. Jampala, S. N., Sarmadi, M., Somers, E. B., Wong, A. C. L., and Denes, F. S., Plasmaenhanced synthesis of bactericidal quaternary ammonium thin layers on stainless steel and cellulose surfaces. Langmuir 2008, 24, 8583-8591. 


\section{Supporting Information}

22. Vabret, A.; Mouthon, F.; Mourez, T.; Gouarin, S.; Petitjean, J.; Freymuth, F., Direct diagnosis of human respiratory coronaviruses $229 \mathrm{E}$ and $\mathrm{OC} 43$ by the polymerase chain reaction. J. Virol. Methods 2001, 97, 59-66. 